\title{
Switch Therapy Antibiotik Pasien Apendisitis RSUD Arifin Achmad Provinsi Riau
}

\author{
Ayu Rahmawati ${ }^{1}$, Elka Yuslinda ${ }^{2}$, Hansen Nasif ${ }^{3}$ \\ ${ }^{1}$ Program Studi Farmasi, STIFAR RIAU, Indonesia, ${ }^{2}$ Program Studi Farmasi STIFAR \\ RIAU, Indonesia, ${ }^{3}$ Fakultas Farmasi, Universitas Andalas, Indonesia \\ 1ㅁahmawatiayu@umri.ac.id, 3hansenn ina@yahoo.com
}

\begin{abstract}
Has conducted a study entitled Switching Antibiotic Therapy to Cases of Appendicitis Surgery in Functional Medical Staff of Arifin Achmad Regional General Hospital, Riau Province. This type of research is a retrospective data observation study, medical record data of appendicitis surgery patients during 2010. The method used is the census method. Antibiotics - Oral Substitution Therapy (IAOST) Protocol to medical record data of appendicitis surgery patients at surgical SMF Arifin Achmad Hospital, Riau Province, following: a therapeutic switch (+) of 17\% (29 cases), a percentage that met the switch therapy criteria and did not occur switch therapy $(\Delta)$ of $67 \%$ (114 cases), the percentage that did not meet the switch therapy criteria and switch therapy occurred $(\mathrm{X})$ by $6 \%$ (11 cases), the percentage that did not meet the switch therapy criteria and no therapeutic switch (V) 17\% (17 cases).
\end{abstract}

Key words: Switch therapy, antibiotics, appendicitis

Abstrak Telah dilakukan penelitian yang berjudul Switch Therapy Antibiotik pada Kasus Bedah Apendisitis di Staf Medik Fungsional Rumah Sakit Umum Daerah Arifin Achmad Provinsi Riau. Jenis penelitian ini adalah penelitian observasi data retrospektif, data rekam medik pasien bedah apendisitis selama tahun 2010. Metoda yang digunakan adalah metoda sensus. Penelitian ini menyimpulkan bahwa switch therapy berdasarkan pedoman perubahan terapi antibiotik intravena ke oral/ Intravenous Antibiotic - Oral Switch Therapy (IAOST) Protocol terhadap data rekam medik pasien bedah apendisitis di SMF bedah RSUD Arifin Achmad Provinsi Riau sebagai berikut : persentase yang memenuhi kriteria switch therapy dan terjadi switch therapy (+) sebesar 17\% (29 kasus), persentase yang memenuhi kriteria switch therapy dan tidak terjadi switch therapy $(\Delta)$ sebesar 67\% (114 kasus), persentase yang tidak memenuhi kriteria switch therapy dan terjadi switch therapy (X) sebesar 6\% (11 kasus), persentase yang tidak memenuhi kriteria switch therapy dan tidak terjadi switch therapy (V) sebesar 17\% (17 kasus).

Kata kunci : Switch therapy, antibiotik, apendisitis

\section{Introduction}

Apendisitis dapat ditemukan pada semua umur. Insiden apendisitis akut di negara maju lebih tinggi dari pada di negara berkembang. Insiden perforasi (pecah) apendisitis akut 90-100\% pada bayi, dan sekitar $50 \%$ pada usia sampai 5 tahun (Sabiston, 1994). Insiden apendisitis tertinggi pada kelompok umur 20-30, khususnya pada lelaki. Dilaporkan insidens perforasi 60\% pada penderita di atas usia 60 tahun (Sjamsuhidajat \& Wim, 2004). Terapi antibiotik juga merupakan salah satu jenis pengobatan yang digunakan pada pasien bedah apendisitis (Masjoer, 2000). Antibiotik merupakan kelompok obat yang paling banyak digunakan. Rata-rata sepertiga dari pasien menerima terapi antibiotik, 40\% nya menerima sediaan intravena. Berdasarkan hasil penelitian yang dilakukan oleh Yunni Priastuti terhadap pola penggunaan antibiotik di ruang rawat inap anak RSUD Arifin Achmad Pekanbaru selama tahun 2007 tercatat penggunaan antibiotik lebih besar dibandingkan dengan obat lainnya, yaitu sebesar 43,56 \% (Priastuti, 2008). Penggunaan antibiotik yang cocok sangatlah penting bagi keamanan pasien dan kesehatan masyarakat (Mertz et al, 2009). 
Ilmu dan pengetahuan tentang obat selalu berubah sehingga menyebabkan ahli kesehatan harus mengetahui perkembangan dalam terapi obat (De Veries et al, 1994). Salah satu cara untuk mengoptimalkan terapi antibiotik adalah untuk segera mengganti terapi intravena ke oral (Mertz et al, 2009). Pergantian switch therapy dilakukan apabila keadaan pasien mampu menerima sediaan oral (Wawruch et al, 2004). Pergantian antibiotik ditetapkan sebagai sebuah pergantian dari sediaan intravena ke oral (Waagsbo et al, 2008). Kriteria untuk melakukan switch therapy antibiotik yang dikenal dengan Intravenous Antibiotic - Oral Switch Therapy (IAOST) Protocol telah diterapkan di Nottingham University Hospital (Clarkson et al, 2010).

\section{The Methods}

Penelitian dilaksanakan pada bulan Juni hingga bulan September 2011 di Rumah Sakit Arifin Achmad Provinsi Riau. Jenis penelitian adalah penelitian observasi menggunakan data retrospektif. Data dikumpulkan dari Rekam medik pasien bedah apendisitis di RSUD Arifin Achmad Provinsi Riau selama bulan Januari hingga bulan Desember 2010. Sampel yang dipilih adalah rekam medik pasien bedah apendisitis rawat inap SMF bedah di RSUD Arifin Achmad Provinsi Riau. Data yang diambil adalah yang memenuhi kriteria inklusi dalam penelitian ini, berupa nomor rekam medik, jenis kelamin, umur, tanggal masuk/tanggal keluar, diagnosa, jumlah nafas, jumlah denyut jantung, suhu badan, antibiotik (rute pemberian, indikasi, dosis) yang digunakan, non antibiotik (dosis) yang digunakan, malabsorpsi, mual, muntah, dan gangguan menelan. Analisa dan penarikan kesimpulan berdasarkan ketepatan dalam pemilihan switch therapy antibiotik dibandingkan dengan standar/literatur yang menjadi rujukan saat ini.

\section{Result and Discussion}

Setelah melakukan penelitian di Rumah Sakit Umum Daerah Arifin Achmad Provinsi Riau terhadap switch therapy antibiotik pada kasus bedah apendisitis didapatlah hasil sebagai berikut : Data rekam medik pasien yang dirawat di SMF Bedah RSUD Arifin Achmad Provinsi Riau dari Bulan Januari sampai dengan Bulan Desember 2010 diperoleh 219 pasien bedah apendisitis. Namun, setelah dilakukan tinjauan terhadap status rekam medik masing-masing pasien diperolehan 171 pasien yang mendapat tindakan bedah apendisitis.

Persentase yang memenuhi kriteria switch therapy dan terjadi switch therapy (Kategori +) sebesar $17 \%$ (29 kasus) dan persentase yang memenuhi kriteria switch therapy dan tidak terjadi switch therapy (Kategori $\Delta$ ) sebesar $67 \%$ (114 kasus) (Lampiran 3, Tabel 5). Persentase yang tidak memenuhi kriteria switch therapy dan terjadi switch therapy (Kategori X) sebesar $6 \%$ (11 kasus) dan persentase yang tidak memenuhi kriteria switch therapy dan tidak terjadi switch therapy (Kategori V) sebesar $10 \%$ (17 kasus) (Lampiran 3, Tabel 5).

Persentase pasien bedah apendisitis yang memenuhi kriteria switch therapy dan terjadi switch therapy (+) terjadi pada hari ke- 2 sebesar 7\% (2 kasus), pada hari ke-3 sebesar 31\% (9 kasus), pada hari ke-4 sebesar $28 \%$ ( 8 kasus), pada hari ke-5 sebesar 10\% (3 kasus), pada hari ke- 6 sebesar 7\% (2 kasus), pada hari ke8 sebesar 10\% (3 kasus),dan pada hari ke-10 sebesar ( 2 kasus). Persentase pasien bedah apendisitis yang memenuhi kriteria switch therapy dan tidak terjadi switch therapy $(\Delta)$ terjadi pada hari ke-2 sebesar $7 \%$ (8 kasus), pada hari ke-3 sebesar 23\% (27 kasus), pada hari ke-4 sebesar 21\% (24 kasus), pada hari ke-5 sebesar $12 \%$ (14 kasus), pada hari ke-6 sebesar 11\% (13 kasus), pada hari ke-7 sebesar 3\% (4 kasus), pada hari ke-8 sebesar 7\% (8 kasus), pada hari ke-9 sebesar 3\% (4 kasus), pada hari ke-11 sebesar 3\% (3 kasus), pada hari ke-12 sebesar 3\% (3 kasus), pada hari ke-14 sebesar 1\% (1 kasus), pada hari ke-15 sebesar 1\% (2 kasus), pada hari ke-17 sebesar 1\% (2 kasus), dan pada hari ke-19 sebesar 1\% (1 kasus).

Persentase pasien bedah apendisitis yang tidak memenuhi kriteria switch therapy dan terjadi switch therapy (X) terjadi pada hari ke-2 sebesar 9\% (1 kasus), pada hari ke-3 sebesar 28\% (3 kasus), pada hari 
ke-4 sebesar 9\% (1 kasus), pada hari ke-5 sebesar 9\% (1 kasus), pada hari ke-6 sebesar 9\% (1 kasus), pada hari ke-8 sebesar 9\% (1 kasus), pada hari ke-10 sebesar 9\% (1 kasus), pada hari ke-11 sebesar 9\% (1 kasus), dan pada hari ke-19 sebesar 9\% (1 kasus). Persentase pasien bedah apendisitis yang tidak memenuhi kriteria switch therapy dan tidak terjadi switch therapy (V) terjadi pada hari ke-2 sebesar $6 \%$ (1 kasus), pada hari ke-3 sebesar 23\% (4 kasus), pada hari ke-4 sebesar 12\% (2 kasus), pada hari ke-5 sebesar 23\% (4 kasus), pada hari ke-6 sebesar 6\% (1 kasus), pada hari ke-7 sebesar 6\% (1 kasus), pada hari ke-8 sebesar 12\% (2 kasus), pada hari ke-9 sebesar 6\% (1 kasus), dan pada hari ke-17 sebesar 6\% (1 kasus).

\section{Conclusion}

Mengacu pada skema pedoman kriteria switch therapy yang menyebutkan bahwa ada 6 jenis kriteria yang dijadikan pedoman dalam pemberian terapi. Beberapa diantaranya menentukan bahwa seorang pasien melanjutkan terapi intravena atau mengganti dengan terapi oral. Kriteria pertama dari switch therapy berhubungan dengan tanda-tanda sepsis. Parameter tanda-tanda sepsis ada 4 jenis: suhu badan, denyut jantung, pernafasan, jumlah sel darah putih. Dikatakan berlangsungnya sepsis apabila berlanjutnya 2 atau lebih tanda-tanda sepsis (Sudoyo, 2009). Demam neutropenia merupakan kriteria kedua dari pedoman ini. Kriteria ketiga berhubungan dengan penanganan infeksi serius yang memerlukan terapi intravena, seperti: meningitis, infeksi endokarditis, dll. Malabsorpsi, antibiotik oral yang sesuai, dan keadaan pasien yang menurun, seperti :mudah muntah, tidak bias melalui mulut, gangguan menelan, dan tidak sadarkan diri adalah kriteria selanjutnya yang harus ditentukan (Clarkson et al, 2011).

Melihat kenyataan yang ada pada data rekam medik pasien bedah apendisitis diketahui terdapat 2 hal yang menjadi kendala peneliti dalam menetapkan kriteria. Kendala pertama adalah penghitungan jumlah sel leukosit yang hanya dilakukan satu kali selama perawatan, yaitu pada hari pertama perawatan. Hal ini sangat disayangkan, dimana kita tahu bahwa besar kecilnya hasil perhitungan jumlah sel darah putih yang diperoleh menjadi tolak ukur untuk melakukan penangan terhadap peradangan yang terjadi. Namun, bila melihat teori sepsis yang ada diketahui bahwa sepsis terjadi bila berlanjutnya 2 atau lebih tanda-tanda sepsis (Sudoyo, 2009). Kendala kedua adalah jumlah neutrofil yang sama sekali tidak dihitung selama masa perawatan. Neutrofil merupakan jenis sel darah putih yang berfungsi untuk menyerang dan merusak bakteri di dalam darah yang bersikurkulasi (Guyton, 1990).

Menimbang kendala di atas, peneliti memutuskan untuk tidak menjadikan perhitungan sel darah putih dan jumlah neutropenia dalam menerapkan kriteria switch therapy karena dikatakan sepsis terjadi apabila terpenuhinya 2 atau lebih tanda-tanda sepsis. Oleh karena itu, kriteria dalam switch therapy pada kasus bedah apendisitis ini berjumlah 5 kriteria, yaitu : berlanjutnya 2 atau lebih tanda-tanda sepsis, infeksi serius yang memerlukan terapi intravena, terjadinya malabsorpsi, antibiotik oral yang sesuai tidak tersedia, terjadinya mual, muntah, dan gangguan menelan.

Penelitian ini dilakakukan secara retrospektif. Penetapan terjadinya sepsis didasarkan pada berlanjutnya 2 atau lebih tanda-tanda sepsis. Penetapan terjadinya malabsorpsi berdasarkan ada atau tidaknya kejadian diare yang tercatat. Penetapan terjadinya mual, muntah, dan gangguan menelan berdasarkan ada atau tidaknya kejadian tersebut tercatat. Penetapan infeksi serius berdasarkan tercatat atau tidaknya data tersebut di rekam medik. Karena peneilitan ini dilakukan secara retrospektif penentuan antibiotik oral yang sesuai tidak tersedia tidak dapat ditentukan sebab data tentang ada atau tidaknya antibiotik oral yang tersedia tidak terdapat dalam catatan rekam medik. Data ada atau tidak tersedianya antibiotik oral yang sesuai berada di Instalasi Farmasi Rumah Sakit. Berdasarkan survey, obat-obat siprofloksasin, amoksisilin, sefiksim, dan sefadroksil selama tahun 2010 tidak terjadi kekosongan. Jadi, obat-obat tersebut selalu tersedia selama tahun 2010.

Berdasarkan data distribusi switch therapy pasien bedah apendisitis di SMF bedah terlihat bahwa persentase yang memenuhi kriteria switch therapy dan tidak terjadi switch therapy (Kategori $\Delta$ ) berada pada urutan tertinggi yaitu sebesar 67\% (Lampiran 3, Tabel 5). Kategori tersebut terjadi pada berbagai 
hari. Kategori $\Delta$ diketahui banyak terjadi pada hari ke-3 dan ke-4, yaitu sebesar 31\% dan 28\%. Dikatakan tidak memenuhinya kriteria switch therapy karena masih belum terpenuhinya kriteria sepsis. Dari tabel rekapitulasi lampiran 3 diketahui jumlah nafas adalah 78-90 kali per menit, jumlah nadi adalah 18-20 kali per menit, dan suhu badan adalah $36,5-36,8^{\circ} \mathrm{C}$. Kecepatan denyut nadi normal adalah 60 sampai 90 denyut per menit (Delf, 1996). Frekuensi pernafasan normal yang sehat berkisar antara 16 sampai 20 kali per menit (Berman et al, 2009). Suhu tubuh normal bekisar antara 36,50 $-37.2^{\circ} \mathrm{C}$ (Sudoyo dkk, 2009). Jadi, kriteria tanda-tanda sepsis memenuhi syarat untuk melanjutkan switch. Kriteria malabsorpsi, mual dan muntah, infeksi, dan antibiotik oral yang sesuai tidak tersedia memenuhi syarat untuk melanjutkan switch.

Berdasarkan hasil penelitian yang dilakukan oleh McLaughlin et al disebutkan bahwa ketepatan pemilihan waktu terealisasinya pedoman Intravenous-Oral Antibiotics Switch Therapy (IVOST) pada kelompok pasien yang menerima pedoman IVOST ini sebesar $90 \%$, bila dibandingkan dengan kelompok yang perubahan terapi intravenanya tidak menggunakan pedoman IVOST (McLaughin et al, 2005).

Berdasarkan data distribusi switch therapy pasien bedah apendisitis di SMF bedah terlihat bahwa persentase yang tidak memenuhi kriteria switch therapy dan tidak terjadi switch therapy (Kategori V) sebesar 10\% (Lampiran 3, Tabel 5). Kejadian kategori $V$ diketahui sering terjadi pada hari ke-3 dan ke-5 dengan masing-masing persentase 23\% (Lampiran 7, Tabel 9). Dari tabel 4 pada kategori V terlihat bahwa jumlah nadi adalah 93-100, jumlah nafas adalah 22-24, dan suhu badan adalah $36,5-36,7^{\circ} \mathrm{C}$. Dikatakan berlangsungnya sepsis apabila berlanjutnya 2 atau lebih tanda-tanda sepsis (Sudoyo, 2009). Jadi, kriteria tanda-tanda sepsis tidak memenuhi syarat untuk melanjutkan switch.

Berdasarkan data distribusi switch therapy pasien bedah apendisitis di SMF bedah terlihat bahwa persentase yang memenuhi kriteria switch therapy dan terjadi switch therapy (Kategori +) sebesar 17\% (Lampiran 3, Tabel 5). Kejadian kategori + diketahui sering terjadi pada hari ke-3 dengan persentase 31\% (Lampiran 4, Tabel 6). Dari tabel 4 pada kategori + terlihat bahwa jumlah nadi adalah 78-90, jumlah nafas adalah $18-20$, dan suhu badan adalah $36,5-36,7^{\circ} \mathrm{C}$. Jadi, kriteria tanda-tanda sepsis memenuhi syarat untuk melanjutkan switch. Kriteria malabsorpsi, mual dan muntah, infeksi, dan antibiotik oral yang sesuai tidak tersedia memenuhi syarat untuk melanjutkan switch.

Berdasarkan data distribusi switch therapy pasien bedah apendisitis di SMF bedah terlihat bahwa persentase yang tidak memenuhi kriteria switch therapy dan tidak terjadi switch therapy (Kategori X) sebesar 6\% (Lampiran 3, Tabel 5). Kejadian kategori X diketahui sering terjadi pada hari ke-3 dengan persentase 28\% (Lampiran 6, Tabel 8). Dari tabel 4 pada kategori X terlihat bahwa jumlah nadi adalah 98105 , jumlah nafas adalah $22-24$, dan suhu badan adalah $36,5-36,7^{\circ} \mathrm{C}$. Jadi, kriteria tanda-tanda sepsis tidak memenuhi syarat untuk melanjutkan switch dan kriteria malabsorpsi, mual dan muntah, infeksi, dan antibiotik oral yang sesuai tidak tersedia memenuhi syarat untuk melanjutkan switch dan switch tidak terjadi.

Sebagai mana yang telah dinyatakan oleh WHO dengan istilah seven star pharmacist: teacher, life-long learner, decision-maker, manager, communicator, leader, care-giver. Khususnya sebagai teacher, life-long learner, dan deccisson. Pelayanan farmasi klinik menekankan pada penerapan kepedulian farmasi (pharmaceutical care) yang menyediakan bukan saja obat-obatan, melainkan juga pelayanan yang perlu untuk memastikan keamanan dan keefektifan terapi (Firmansyah, 2009). Salah satu cara untuk dapat meningkatkan kompetensi ahli fasmasis dalam menghadapi dunia farmasi klinis yang selalu dinamis ialah dengan selalu memelihara suatu kesadaran mutakhir perkembangan dalam praktik dengan cara menghadiri pertemuan ilmiah tentang farmasi, membaca majalah ilmiah dan publikasi ilmiah kesehatan, dan mengadakan perubahan dalam praktiknya sesuai dengan informasi yang diperoleh (Siregar, 2005). Hal ini diperlukan karena mengingat bahwa switch therapy bukanlah suatu program terapi baru. Jika farmasis telah aktif terlibat dalam berbagai keputusan terapi obat khususnya pada kasus ini, maka switch therapy akan berjalan dengan maksimal. 


\section{References}

Anaizi, N., 2011, "Early Conversion to Oral Antimicrobial Therapy", diunduh dari http://www.thedrugmonitor.com/sequential.html [Diakses tanggal 19 April 2011].

Angeli, P., S. Guarda, S. Fasolato, E. Miola, R. Craighero, F. Piccolo, C. Antona, L. Brollos, M. Franchin, U. Cillo, C. Merkel, and A. Gatta, 2006, "Switch Therapy with Ciprofloxacin vs. Intravenous Ceftazidime in the Treatment of Spontaneous Bacterial Peritonitis in Patients with Cirrhosis: Similar Efficacy at Lower Cost", Aliment Pharmacol Ther, Vol 23, 75-84.

Avis,K. E., Lieberman, H. A., and Lachman, L., 1992, Pharmaceutical Dosage Forms: Parenteral Medications, Vol 1, Marcel Dekker, INC, New York.

Baugham, D.C. and JoAnn C. H., 2000, Keperawatan Medical-Bedah: Buku Saku dari Brunner \& Suddarth, Terjemahan Yasmin Asih, EGC, Jakarta.

Behrman, R. E., Robert M. K. and Ann M. A., 1999, Ilmu Kesehatan Anak Nelson, Vol 2, Ed 15, Terjemahan A. Samik Wahab, EGC, Jakarta.

Berman, A., Shirlee S., Barbara K., and Glenora E., 2009, Buku Ajar Keperawatan Klinis Kozier \& Erb, Ed 5, Terjemahan Eny Meiliya, Esty Wahyuningsih, \& Devi Yulianti, EGC, Jakarta.

Clarkson, A., Vivienne W. and Tim H., 2011, "Guidline for the Intraveneous to Oral Switch of Antibiotic Theraphy, Nottingham University Hospitals", diunduh dari http://www.nuh.nhs.uk/Default.aspx [Diakses tanggal 19 April 2011].

Cunha, B A., 2008, "Oral and I.V.-to P.O. Switch Antibiotic Therapy of Hospitalized Patients with Serious Infection”, Scandinavian Journal of Infectious Diseases, Vol 40, 1004-1006.

Darmadi., 2008, Infeksi Nosokomial: Problematika dan Pengendaliannya, Jakarta, Salemba Medika.

Delf, M. H., 1996, Major Diagnosis Fisik, Ed 9, Terjemahan Moelia Radja Siregar, EGC, Jakarta.

Depkes, 2000, Informatorium Obat Nasional Indonesia 2000, CV Agung Seto, Jakarta.

Dipiro, J. T., Robert L. T., Gary C., Barbara G. W., and L. M. P., 2005, Pharmacotherapy A Pathophysiologic Approach, Sixth Edition, The McGraw-Hill Companies, United State of America.

Dorland, W. A. N., 2002, KamusKedokteran Dorland, Terjemahan Huriawati Hartanto, Jakarta, EGC.

Fawcett, D. W., 2002. Buku Ajar Histologi, Ed 12, Terjemahan Jan Tambayong, EGC, Jakarta.

Firmansyah, M., 2009, Tata Cara Mengurus Perizinan Usaha Farmasi dan Kesehatan, Visimedia, Jakarta

Ganiswarna, S. G., Rianto S., Frans D. S., Purwantyastuti, dan Nafrialdi, 1995, Farmakologi dan Terapi, Ed 4, Departemen Farmakologi dan Terapi Fakultas Kedokteran Universitas Indonesia, Jakarta.

Gilman, A. G., 2007, Goodman \& Gilman : Dasar Farmakologi Terapi, Ed 10, Terjemahan Tim ahli bahasa sekolah farmasi ITB, EGC, Jakarta.

Guyton, A.C., 1990, Fisiologi Manusia dan Mekanisme Penyakit, Ed 3, Terjemahan, Petrus Andrianto, EGC, Jakarta.

Hamilton, J. M. T., and Miller, 1996, "Switch Therapy : the Theory and Practice of Early Change from Parenteral to Non Parenteral Antibiotic Administration", Journal Readership Survey, Vol 2, 12-19.

Hobler, K. E., 1998, "Acute and Suppurative Appendicitis: Disease Duration and Its Implications for Quality Improvement" The Permanente Jurnal Spring, 1998, Vol 2, No 2, 1-91.

Junqueira, L. C., Jose C., and Robert O. K., 1997, Histologi Dasar, Ed 8, Terjemahan Sugiarto Komala, EGC, Jakarta.

Masjoer, A., 2000, Kapita Selekta Kedokteran, Ed 3, Media Aesculapius, Jakarta.

Mclaughlin, C.M., N. Bodasing, A.C. Boyter, C.Fenelon, J.G. Fox and R.A. Seaton, 2005, "PharmacyImplemeted Guidelines on Switching from Intravenous to Oral Antibiotics : An Intervention Study", $Q J$ Med, Vol 98, 745-752.

Mertz, D., Michael K., Patricia H., Markus L. L., Herbert P., Balthasar H., Gian K., Manuel B., Ursula F. and Stefano B., 2009, "Outcomes of Early Switching from intravenousto oral antibiotics on medical wards", Journal of Antimicrobial Chemotherapy, Vol 64, 188-199.

Mutschler, E., 1991, Dinamika Obat, Ed 5, terjemahan Mathilda B. Widianto dan Anna Setiadi Ranti, Penerbit ITB, Bandung.

Muttaqin, A. dan Sari, K., 2009, Asuhan Keperawatan Perioperatif: Konsep, Proses, dan Aplikasi, Penerbit Salemba Medika, Jakarta. 
Patel, P. R., 2005, Lecture Notes: Radiologi, Ed 2, Terjemahan vidhia Umami, Penerbit Erlangga, Jakarta. Priastuti, Y., 2008, Pola Penggunaan Antibiotik pada Pasien di Ruang Rawat Inap Anak Rumah Sakit Umum Daerah Arifin Achmad Pekanbaru, Sekolah Tinggi Ilmu Farmasi Riau, Pekanbaru.

Price, S. A. dan Lorraine M. W., 2005, Patofisiologi : Konsep Klinis Proses-proses Penyakit, Ed 6, Terjemahan Brahm U. Pendit, EGC, Jakarta.

Putz, R., dan Reinhard P., 2006, Sobota : Atlas Anatomi Manusia, Ed 22, Terjemahan Y. Joko Suyono, EGC, Jakarta.

Ramirez, J. A, 1998, "Switch Therapy with Beta-Lactam/Beta-Lactamase Inhibitors in Patients with Community-Acquired Pneumonia", The Annals of Pharmacotherapy, vol 23, 22-26.

Ramirez, J. A., Sergio V., Gilbert W. R., Michael E. B., Allie W., Scott S., David N., John B., Mian M., and Anna H., 1999, "Early Switch From Intravenous to Oral Antibiotics and Early Hospital Discharge : A Prospective Observational Study of 200 Consecutive Patients with Community-Acquired Pneumonia", Arch Intern Med, Vol 159, 2449-2454.

Ruiz, G. O., Perafan, M. A., Faist, E., and Castell, C. D., 2006, Sepsis, Ed 2, Springer Science+Business Media, Ind, United State of America.

Sabiston, D. C., 1994, Buku Ajar Bedah, Jilid 2, Terjemahan Petrus Andrianto, EGC, Jakarta.

Siregar, C. J. P., 2005, Farmasi Rumah Sakit : Teori dan Penerapan, EGC, Jakarta.

Sjamsuhidajat, R. dan Win D. J., 2004, Buku-Ajar Ilmu Bedah, Ed 2, EGC, Jakarta.

Sloane, E., 2003, Anatomi dan Fisiologi untuk Pemula, Terjemahan Palupi Widyastuti, EGC, Jakarta.

Sudoyo, A. W., Bambang S., Idrus A., Marcellus S. K., and Siti S., 2009, Buku Ajar Ilmu Penyakit Dalam, Ed V, Jilid III \& I, Pusat Penerbitan Departemen Ilmu Penyakit Dalam Fakultas Kedokteran Universitas Indonesia, Jakarta.

Waagsbo, B., Andres S., and Else Q. P., 2008, "Reduction of Unnecessary IV Antibiotic Days Using General Criteria For Antibiotic Switch", Scandinavian Journal of Infectious Diseases, Vol 40, 468-473.

Widjanarko, A., Sudoyo, A. W. and Salonder, H., 2007, Buku Ajar Ilmu Penyakit Dalam Jilid II, Edisi IV, Jakarta, Departemen Ilmu Penyakit Dalam Fakultas Kedokteran Universitas Indonesia.

Wong, B. L. K., and Armando G., 2011, "Intraveonus to Oral Switch of Antibiotics", Journal of Clinical Audits, Vol 3, 1-7. 